\title{
Expressions of genes encoding steroidogenic enzymes and their role in prostate carcinogenesis
}

\author{
Bartosz A. Frycz, Paweł P. Jagodziński \\ Chair and Department of Biochemistry and Molecular Biology, Poznan University of Medical Sciences
}

\begin{abstract}
The concentration of sex steroid hormones in the prostate gland is controlled by their local synthesis and metabolism. These processes involve steroid metabolizing (steroidogenic) enzymes, which are necessary to produce the active form of androgens and estrogens at specific locations. Changes in gene expression of the steroid metabolizing enzymes may play an important role in prostate carcinogenesis by regulating sex steroid concentration in the prostate gland. The purpose of this review is to gather the most important reports connected with gene expression of the steroidogenic enzymes and to find correlations between gene expression and tumorigenesis in the prostate gland.
\end{abstract}

Key words: prostate cancer, steroidogenesis, steroidogenic enzymes, steroid hormone.

\section{Introduction}

Malignant neoplasms, as the second most popular cause of death worldwide after cardiovascular diseases, pose a serious health problem. One of the most common malignant neoplasms in men is the prostate cancer (PCa). In 2009 in the United States 192,280 people were diagnosed with this cancer, of whom 27,360 died [1]. In 2006 in Poland over five thousand patients died of $\mathrm{PCa}$, out of the total 71,000 patients diagnosed with neoplastic diseases. Thus, PCa was the third type of cancer with the highest mortality rate [2]. Despite high prevalence of $\mathrm{PCa}$ and numerous scientific research programs, the mechanisms underlying its development still remain unclear. The most important risk factors of the prostate gland malignancy include age, race and family history of the disease. PCa is rarely found in people below forty, but above that age the incidence rate increases dramatically, as compared with any other type of cancer. Apart from age, an important factor predisposing to $\mathrm{PCa}$ is the race. The most vulnerable ethnic group are the African Americans, and the least the Asian population, which may be associated with their diet and lifestyle. The risk is also increased in the cases of family history of $\mathrm{PCa}$, which is probably related to genetic factors [3]. Steroid hormones may also be important in the PCa development, as their presence is essential for a proper functioning and growth of the prostate gland. The steroid hormones are supplied to the prostate with the blood flow, but thanks to the local expression of steroidogenic enzymes the steroid hormones can be also synthesized and metabolized within the gland. Variations in the expression pattern of the steroidogenic hormones during neoplastic transformation may significantly affect the intracellular concentration of steroid hormones in the prostate gland and thus play a role in the cancer pathophysiology [4]. Identification of possible gene expression alterations within the prostate, crucial for extragonadal synthesis of steroid hormones, may be helpful in better understanding of PCa development mechanisms. Consequently, this may be a starting point for working out new therapeutic approaches, based on analogs or steroidogenic enzyme inhibitors.

\section{Steroid hormones and the prostate cancer}

The role of steroid hormones in the prostate gland carcinogenesis became the focus of scientific research in 
1941, when Huggins and Hodges demonstrated the effect of surgical castration and anti-androgen supply on a reduced level of acid phosphatase in the blood serum of PCa patients. Acid phosphatase was the first biomarker, whose elevated level indicated the PCa. Additionally, higher concentration of acid phosphatase was noticed after androgen injection in patients with advanced PCa [9]. These studies identified testosterone as a major factor involved in the neoplastic transformation of the prostate cells, and initiated the use of a therapy aimed at inhibition of testosterone biosynthesis. In most cases, blocking testosterone production by means of surgical or pharmacological castration results in initial tumor regression, but over time the tumor becomes androgen-independent [10]. Subsequent studies have provided further evidence of the androgen role in PCa pathogenesis. It was demonstrated that the incidence of $\mathrm{PCa}$ in patients castrated before puberty were extremely rare [11]. Moreover, the effect of DHT on the regulation of proliferation and apoptosis balance in the prostate cells was showed. Disturbance of this processes may lead to uncontrolled cell division and eventually to cancer development [4]. The data obtained in the Prostate Cancer Prevention Trial revealed that blocking the conversion of testosterone to DHT by finasteride ( $5 \alpha$-reductase inhibitor) reduced PCa incidence. Unfortunately, prolonged use of finasteride was associated with an increased risk of other tumors and numerous side effects [12]. Further information concerning the effects of androgens on the PCa development was derived from animal models. For example, increased PCa incidence was observed in Noble rats following a long-term supply of testosterone [13]. Nobel rats were also a model in which synergistic effects of androgens and estrogens on the induction of dysplasia and hyperplasia of the glandular epithelium were demonstrated [14].

Another group of sex hormones that regulate growth and differentiation of the prostate cells and may be involved in their carcinogenesis are estrogens. The estrogens affect the prostate gland in a direct and indirect way. Indirect action is manifested by inhibition of androgen synthesis and secretion by means of estrogen influence on the hypothalamic-pituitary-gonadal axis or directly on the testes [15]. The direct mechanisms have been unveiled experimentally. It was found that estrogens, in both humans and rats, stimulated DNA synthesis and induced metaplastic lesions in the prostate epithelium $[16,17]$. In rats, the presence of high doses of estrogen in the first five days postnatally triggered significant changes in the development and functioning of the prostate in later life. These changes included inhibition of the prostate growth, inflammations, epithelial hyperplasia and dysplastic lesions that histologically resembled prostatic intraepithelial neoplasia (PIN) [18].

The relationship between serum level of the steroid hormones and PCa incidence remains unclear. It is difficult to explain the increased incidence of PCa with age, when androgen bioavailability decreases. It may be speculated that the estrogens replace testosterone in the induction of neoplastic lesions, however, this assumption has not been sufficiently proved [19]. Most studies showed no relationship between the levels of steroid hormones and sex hormone binding protein (SHBP) in serum, and increased risk of PCa [20]. However, the article by Gann et al. [21] reported an enhanced risk of PCa in the patients with increased testosterone level and low level of SHBP. Unfortunately, this type of study may be burdened with serious errors due to using different laboratory methods for the determination of hormone blood levels, current endocrine status, etc. [20].

\section{Steroidogenesis in the prostate gland}

Androgens are the main type of steroid hormones with a fundamental role in the prostate growth and functioning. Their de novo production occurs in the testes and adrenal cortex. Peripheral tissues, such as the prostate or skin, may synthesize androgens from the precursors supplied with blood. This process depends on the expression of steroidogenic enzymes, involving different types of dehydrogenases: $3 \beta$-hydroxysteroid dehydrogenase (HSD3 $\beta)$, 17 $\beta$-hydroxysteroid dehydrogenase (HSD17 $\beta$ ), 3 $\alpha$-hydroxysteroid dehydrogenase (HSD $3 \alpha$ ) and $5 \alpha$-reductase. The most important androgen is testosterone, produced from androstenedione (A-dione) in testicular Leydig cells by HSD17 $\beta 3$. Testosterone may be also synthesized in the prostate, however, this process is mediated by another enzyme - HSD17 $\beta 5$. In contrast, A-dione is formed through the conversion of an adrenal precursor dehydroepiandrosterone (DHEA), catalyzed in the prostate basal epithelial cells by HSD3 $\beta 1$. In the prostate testosterone is converted to its most active metabolite, dihydrotestosterone (DHT), by type 2 5 $\alpha$-reductase (SRD5A2) [5]. DHT level in the tissue is much higher than in blood [6]. An alternative pathway of DHT formation involves the conversion of $5 \alpha$-androstan-3 $3,17 \beta$-diol ( $3 \alpha \mathrm{A}$ diol) mediated by type $3 \mathrm{HSD} 3 \alpha$. Both testosterone and DHT inactivation is catalyzed by HSD17 $\beta 2$. As a 
result, these androgens are converted to A-dione and

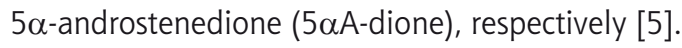

The prostate gland may produce not only androgens, but also estrogens. In this process, aromatase (CYP19) converts testosterone into the most active form of estrogen - 17 $\beta$-estradiol (E2). A-dione may also be converted, but only into estrone (E1) that exhibits poor biological activity [7]. HSD17 $\beta$ 1, 7 and 12 can reduce $\mathrm{E} 1$ to $\mathrm{E} 2$. An opposite reaction is mediated by HSD17 $\beta 2,4,8,10$ and 11, displaying oxidative activity [8]. These mechanisms are illustrated in figure 1.

\section{Expression of steroidogenic enzymes in the prostate cancer}

Intracellular levels of steroid hormones in the peripheral tissues depend on their supply with blood and local biosynthesis and metabolism. Peripheral tissues, including the prostate gland, are not capable of de novo steroid synthesis, but they contain the enzymes that catalyze the formation of active androgens and estrogens from adrenal derived precursors [22]. The main enzymes involved in the local steroidogenesis in the prostate gland are steroid sulfatases, $3 \beta$-hydroxysteroid hydrogenases, $17 \beta$-hydroxysteroid dehydrogenases, $3 \alpha$-hydroxysteroid dehydrogenases, $5 \alpha$-reductases and aromatases [4].

\section{Steroid sulfatases}

Steroid sulfatases (STS) are responsible for the conversion of estrone sulphate (E1S) to biologically active estrone (E1) and dehydroepiandrosterone sulfate (DHEAS) to DHEA [23]. STS expression has already been investigated during studies on other hormonedependent neoplasms, such as breast cancer and endometrial cancer [24]. It was found that breast cancer was associated with higher level of steroid sulfatase mRNA and protein, as compared to normal tissues [25] [26]. Similarly, the expression level of STS may also be important in the PCa development, considering its role in the synthesis of androgens and estrogens [27]. The studies by Nakamura et al. [28] demonstrated that estrogen production in the prostate was to a greater

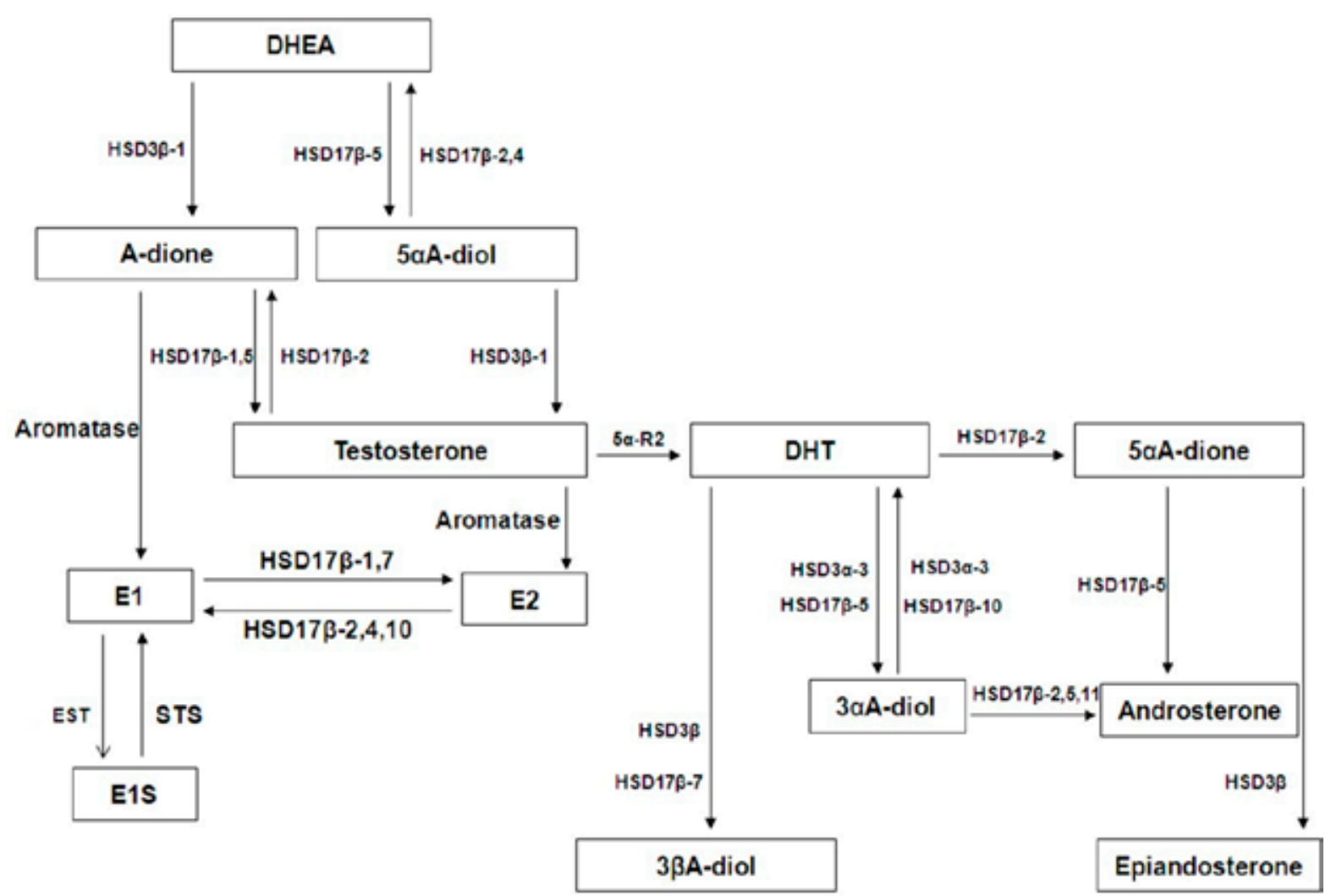

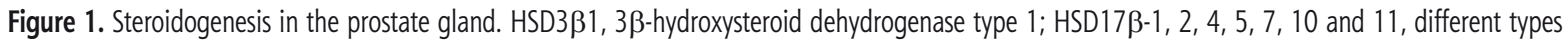
of $17 \beta$-hydroxysteroid dehydrogenases; $5 \alpha$-R2, $5 \alpha$-reductase type 2, DHEA, dehydroepiandrosterone; A-dione, androstenedione; $5 \alpha A$-diol, $5 \alpha-$ androstenediol; E1, estrone, E2, estradiol, DHT, dihydrotestosterone; $3 \beta A$-diol, $5 \alpha$-androstan-3 $\beta, 17 \beta$-diol; $3 \alpha$ A-diol, $5 \alpha$-androstan-3 $3 \alpha, 17 \beta$-diol; $5 \alpha \mathrm{A}$ dione, $5 \alpha$-androstenedione 
extent mediated by STS than by CYP19. STS presence was confirmed in the majority of human neoplastic tissues, and PCa cell lines, but it was not detected in benign prostatic hyperplasia (BPH).

\section{$3 \beta$-hydroxysteroid dehydrogenases}

$3 \beta$-hydroxysteroid dehydrogenase (HSD3 $\beta$ ) are bifunctional dimeric enzymes necessary in the biosynthesis of all classes of steroid hormones. There are two human isoforms of this enzyme: HSD3 $\beta 1$ and HSD3 $\beta 2$ [29]. The first isoform is expressed only in placenta and peripheral tissues, such as mammary gland, prostate gland, and skin, and the second is expressed particularly in steroidogenic tissues, such as adrenal glands, testes and ovaries, where it is involved in the conversion of dihydrotestosterone to inactive metabolites. The genes encoding these enzymes are, due to their important role in androgen metabolism, classified as candidate genes for PCa. Numerous polymorphisms have been identified in both genes and links have been found between some of them and increased PCa risk [30]. Stanbrough et al. reported overexpression of HSD3 $\beta 2$ gene and concluded that it was associated with a tumor adaptation to anti-androgen therapy [31].

\section{$17 \beta$-hydroxysteroid dehydrogenases}

The family of $17 \beta$-hydroxysteroid dehydrogenases consists of a group of enzymes that catalyze the conversions of $17 \beta$-ketosteroids and $17 \beta$-hydroxysteroids [32]. Both estrogens and androgens display their highest activity in $17 \beta$-hydroxy form, which is present in estradiol and testosterone. Thus, HSD17 $\beta$ enzymes play a crucial role in the regulation of steroid hormones by controlling the formation and inactivation of androgens and estrogens. So far, at least 11 types of $17 \beta$ hydroxysteroid dehydrogenases have been characterized in different species, including 9 types in humans [33]. PCa studies revealed a differential expression of a few enzymes from 17 $\beta$-hydroxysteroid dehydrogenase family, including increased expression of reducing enzymes that catalyze a conversion of precursors to active androgens and estrogens (HSD17 $\beta 3$, HSD17 $\beta 5$ and HSD17 $\beta 7$ ), and reduced expression of oxidative enzymes, catalyzing the opposite reactions (HSD17 $\beta 2$ ) $[31,34]$. These data suggest a shift in androgen and estrogen metabolism within a tumor, towards the formation of testosterone, DHT, and E2. Moreover, declined expression of HSD17 $\beta 2$ that protects tissues against excessive synthesis of E2 may be associated with higher level of this hormone in the prostate and stimulation of cancer cell proliferation. It is important that these processes take place in the phase where PCa development is androgen-independent [35].

\section{$3 \alpha$-hydroxysteroid dehydrogenases}

Type 2 of $3 \alpha$-hydroxysteroid dehydrogenase ( $3 \alpha$-HSD) belongs to the family of aldo-keto reductases (AKR) and it is abbreviated as AKR1C3. In the prostate, this enzyme catalyzes conversion of $\Delta 4$-androstene-3,17dione to testosterone, $5 \alpha$-dihydrotestosterone to $5 \alpha$-androstane- $3 \alpha, 17 \beta$-diol ( $3 \alpha$-diol) and $3 \alpha$-diol to androsterone. Thus, AKR1C3 may control the androgen balance in the prostate gland by transactivation of the androgen receptor [36]. Fung et al. [37] synthesized a highly specific antibody and used it to demonstrate cytoplasmic immunoreactivity of AKR1C3 protein in non-epithelial prostate components, such as endothelial and perineurial cells, stromal cells and smooth muscle cells. Immunoreactivity was also detected in transitional urothelial epithelium, prostatic urethra, and vas deferens epithelium. In contrast to non-epithelial cells, the glandular epithelial cells show only slight or no immunoreactivity to this highly specific antibody. Positive cytoplasmic immunoreactivity of AKR1C3 was detected in 9 of 11 cases of prostate cancer, indicating overexpression of AKR1C3 in PCa. These results confirm earlier reports on elevated level of mRNA for such reducing enzymes as AKR1C2 [38] and AKR1C3 [39] in primary cultures of prostate epithelial cells derived from prostate cancer regions. Fung et al. also reported that the second type of $3 \alpha$-hydroxysteroid dehydrogenase was coexpressed with the androgen receptor in the same prostatic cell types, and particularly in the case of prostate cancer, however, this was not confirmed in immunohistochemical tests. It was found [37] that increased level of AKR1C3 might not only promote growth of the prostate cancer cells, but it also supported angiogenesis by raising the levels of VEGF [40]. Low immunoreactivity of AKR1C3 protein in normal prostatic epithelium, as compared to neoplastic tissues, was corroborated by other studies [41], which may indicate a role of this enzyme in promoting tumor growth and angiogenesis.

\section{$5 \alpha$-reductases}

Testosterone is a dominant circulating androgen, and it may be present in blood as a free form or as SHBP. The free testosterone fraction may diffuse into the prostate cells, where it is irreversibly converted 
into dihydrotestosterone by NADPH-dependent $\triangle 4$-3ketosteroid-5 $\alpha$-oxidoreductase ( $5 \alpha$-reductase) [42]. Two types of $5 \alpha$-reductase have been identified in humans, and the prostate contains almost exclusively the second type, encoded by SRD5A1 gene [43]. Results from in vitro studies suggest that the prostatebased conversion of testosterone to DHT, catalyzed by type 2 of $5 \alpha$-reductase, may be the most important factor determining the risk of PCa [44]. SRD5A1 overexpression was found in androgene-independent prostate cancer. Enhanced expression this gene suggests intensified conversion of testosterone to its most active form - dihydrotestosterone, which may also contribute to the activation of the androgen receptor in PCa [32]. A49T mutation in $5 \alpha$-reductase gene raises the enzyme activity fivefold [45]. A correlation was also revealed between SRD5A1 polymorphism and $\mathrm{PCa}$ risk [46]. In the Japanese population, characterized by low incidence of prostate cancer [47], the activity of $5 \alpha$-reductase is much lower than in the American population, where the incidence rate is very high.

\section{Aromatases}

Prostate cells are capable of synthesizing estrogens from androgens by means of aromatase [8]. Activity of this enzyme was confirmed in prostate cancer cell lines and the cells derived from benign prostate hyperplasia, but it was not detected in normal epithelium. This indicates a possibility of local conversion of testosterone to estrogens that occurs in $\mathrm{PCa}$, which may eventually result in intratumoral increase of estrogen levels [48]. It was also showed that obesity, which is most often associated with elevated androgen aromatization, was correlated with poor histology in young PCa men, particularly those younger than 50 years [49]. Prostate tumorigenesis involves changes in the cellular expression of aromatase. It is believed that this may be related to the development and progress of PCa, in a mechanism similar to the one described earlier for the breast cancer [50]. Inhibited estrogen biosynthesis in aromatase knockout mice led to the prostate enlargement, but no signs of a malignant transformation were observed [51]. There are also reports in which aromatase expression was detected in neither benign prostatic hyperplasia, nor prostate cancer cell lines [52], and therefore the role of this enzyme in PCa development remains unclear. Polymorphisms of aromatase encoding CYP19 may also play an important role in the development of prostate cancer [53], however, conclusive evidence is lacking due to numerous limitations of such studies.

\section{Diagnostic potential}

Early and accurate diagnosis is a critical issue for subsequent treatment of PCa. Unfortunately, common diagnostic tools have some disadvantages and in many cases are not sufficient for proper PCa recognition. The standard test used for prostate-specific antigen (PSA) amount in a blood has multiple limitations e.g. not distinguishing well between BPH and PCa and having a normal PSA levels does not completely rule out the cancer [53]. Similar problems can occur during Digital rectal examination (DRE) which is also used for $\mathrm{PCa}$ detection. Occasionally men with normal DRE results suffer from PCa. In opposite, men with an abnormal PSA level or positive DRE, diagnosed and treated for PCa, would have never develop disease to advanced stage. Biopsy is considered as accurate and direct way for an indication of tumor cells presence in the gland, however, collecting tissues from the small area raises the possibility that cancer can be simply missed [54]. Some of these disadvantages can be overcome by the introduction of new prognostic tests based on genes expression. Prolaris is the new diagnostic test for $\mathrm{PCa}$ which measures the expression level of genes responsible for cancer cells division [55]. Some other tests like: Oncotype DX, measure the expression level of various genes implicated in PCa [56]. These tests are used to provide an additional information in predicting disease aggressiveness. In cases when the first biopsy result was negative and patient has still an elevated level of PSA, decision about the next biopsy can be make on the basis of new Hologic [57], MDxHealth [58] and Mitomics [59] tests. During prostate carcinogenesis an altered expression of genes encoding steroidogenic enzymes can occur. This abnormalities can be a potential source for new diagnostic tools development as well as for a choosing of the most effective therapy. However, better understanding of abnormal genes expression and the role of steroid hormones in prostate carcinogenesis is needed.

\section{Clinical applications}

Androgen-deprivation therapy (ADT) remains the principal treatment for advanced and metastatic PCa. Androgen withdraw can be achieved with gonadotropinreleasing hormone analogs or anti-androgen agents. Treatment with gonadotropin-releasing hormone analogs like leuprolide or goserelin is called chemical castration due to the fact they lower androgens level, whereas anti-androgens (e.g. flutamide or bicalut- 
amide) directly block the androgen receptor. The benefits of ADT include disease remission, symptom reduction and a marked clinical response. Decrease in testosterone plasma level results in apoptosis of most $\mathrm{BPH}$ as well as PCa cells. However, after an initial response to ADT, disease progress occur regardless of testosterone level. Somehow, tumor cells become able to maintain the transcription of androgen related genes. This stage of cancer is known as castrate-resistant prostate cancer (CRPC) and is associated with a poor prognosis and short survival. Mean survival time for metastatic CRPC is only in range of $16-18$ months $[60,61]$. Some evidence $[62,63]$ suggest, that up-regulation of genes encoding enzymes involved in androgen biosynthesis such as AKR1C3 can be key event in tumor adaptation to ADT. Moreover, other studies [64, 65] suggest PCa bone metastases ability to conversion of adrenal androgens to testosterone and DHT. Due to these facts, steroidogenic enzymes can be important target for the development of new therapies for PCa based on the use of their analogs and inhibitors. In recent years new strategies to inhibit AR signaling have been emerge. It was shown, that treatment with cytochrome P450-c17 (CYP17) inhibitor, abiraterone acetate, results in suppression of adrenal derived androgens. It was associated with increased survival time and increased time to PSA progression [66]. Other drug with anti-androgen effect is ketoconazole that blocks P450s involved in ergosterol biosynthesis [67].

In light of these observations, steroidogenic enzymes inhibition has high potential value in CRPC treatment however certain conclusions required more time and researches.

\section{Conclusions}

Steroid hormones participate in the regulation of growth and functioning of the prostate gland and its pathogenesis. The amount of steroid hormones in the tissue depends on blood supply and local activity of steroidogenic enzymes responsible for their biosynthesis and inactivation.

Scientific studies published so far have indicated a shift in the steroidogenic enzymes expression pattern towards the synthesis of active forms of androgens and estrogens during prostate carcinogenesis and androgene-independent tumor growth phase. This process may be greatly influenced by polymorphisms of genes encoding the steroidogenic enzymes. Unfortunately, there are too few publications to draw ultimate conclusions. Identification of altered expression of the ste- roidogenic enzymes during neoplastic transformation of the prostate gland may provide valuable information on the mechanisms regulating this process. This knowledge may be extremely useful for the development of new therapies for prostate cancer, based on the use of analogs and inhibitors of the steroidogenic enzymes. However, it is still difficult to demonstrate a direct contribution of individual factors to the initiation and progression of PCa. More data is needed to fully understand the phenomena occurring during the prostate carcinogenesis.

\section{Conflict of interest}

The authors declare that there are no conflicts of interest.

\section{References}

1. Bethesda MD. Cancer Trends Progress Report 2009/2010 Update, National Cancer Institute, NIH, DHHS. 2010 Aug. http://progressreport.cancer.gov

2. Wojciechowska U, Didkowska J, Zatoński W. Nowotwory złośliwe w Polsce w roku. 2006. Centrum Onkologii Instytut im. M. Skłodowskiej-Curie, Warszawa. 2008.

3. Bostwick DG, Burke HB, Djakiew D, Euling S, Ho SM, Landolph J et al. Human Prostate Cancer Risk Factors. Cancer. 2004 Nov;101(10):2371-490.

4. Soronen P, Laiti M, Törn S, Härkönen P, Patrikainen L, Li Y et al. Sex steroid hormone metabolism and prostate cancer. J Steroid Biochem Mol Biol. 2004 Nov;92(4):281-6.

5. Sharifi N. Minireview: Androgen metabolism in castration-resistant prostate cancer. Mol Endocrinol. 2013 May;27(5):708-14.

6. Hsing AW. Hormones and prostate cancer: what's next? Epidemiol Rev. 2001;23(1):42-58.

7. Harkonen PL, Makel SI. Role of estrogens in development of prostate cancer. J Steroid Biochem Mol Biol. 2004 Nov;92(4):297-305.

8. Luu-The V. Analysis and characteristics of multiple types of human 17 beta-hydroxysteroid dehydrogenase. J Steroid Biochem Mol Biol. 2001 Jan-Mar;76(1-5):143-51.

9. Huggins C, Hodges CV. Studies of prostatic cancer: effect of castration, estrogen and androgen injections on serum phosphatases in metastatic carcinoma of the prostate. 1941. J Urol. 2002 Jul;168(1):9-12.

10. Feldman BJ, Feldman D. The Development Of Androgen-Independent Prostate Cancer. Nat Rev Cancer. 2001 Oct; 1(1):34-45.

11. Hovenian MS, Deming CL. The heterologous growth of cancer of the human prostate. Surg Gynecol Obstet. 1948 Jan;86(1):29-35.

12. Thompson IM, Goodman PJ, Tangen CM, Lucia MS, Miller GJ, Ford LG et al. The influence of finasteride on the development of prostate cancer. N Engl J Med. 2003 Jul;349(3):215-224.

13. Noble RL. The development of prostatic adenocarcinoma in Nb rats following prolonged sex hormone administration. Cancer Res. 1977 Jun;37(6):1929-1933.

14. Lau KM, Leav I, Ho SM. Rat estrogen receptor-alpha and -beta and progesterone receptor mRNA expression in 
various prostatic lobes and microdissected normal and dysplastic epithelial tissues of the Noble rats. Endocrinology. 1998 Jan;139(1):424-7.

15. Harkonen PL, Makel SI. Role of estrogens in development of prostate cancer. J Steroid Biochem Mol Biol. 2004 Nov;92(4):297-305.

16. Nevalainen MT, Valve EM, Mäkelä SI, Bläuer M, Tuohimaa PJ, Härkönen PL. Estrogen and prolactin regulation of rat dorsal and lateral prostate in organ culture. Endocrinology. 1991 Aug;129(2):612-22.

17. Nevalainen MT, Härkönen PL, Valve EM, Ping W, Nurmi M, Martikainen PM. Hormone regulation of human prostate in organ culture. Cancer Res. 1993 Nov;53(21):5199-207.

18. Pylkkanen L, Santti R, Newbold R, McLachlan JA. Regional differences in the prostate of the neonatally estrogenized mouse. Prostate. 1991;18(2):117-29.

19. Friedman AE. The Estradiol-Dihydrotestosterone model of prostate cancer. Theor Biol Med Model. 2005 Mar; 18;2:10.

20. Roddam AW, Allen NE, Appleby P, Key TJ. Endogenous sex hormones and prostate cancer: a collaborative analysis of 18 prospective studies. J Natl Cancer Inst. 2008 Feb;100(3):170-83.

21. Gann PH, Hennekens CH, Ma J, Longcope C, Stampfer MJ. Prospective study of sex hormone levels and risk of prostate cancer. J Natl Cancer Inst. 1996 Aug;88(16):1118-26.

22. Labrie F, Luu-The V, Lin SX, Simard J, Labrie C. The Role of 17 beta-hydroxysteroid dehydrogenases in sex steroid formation in peripheral intracrine tissues. Trends Endocrinol Metab. 2000 Dec;11(10):421-7.

23. Nakamura $Y$, Miki $Y$, Suzuki $T$, Nakata $T$, Darnel AD, Moriya $T$ et al. Steroid sulfatase and estrogen sulfotransferase in the atherosclerotic human aorta. Am J Pathol. 2003 Oct;163(4):1329-39.

24. Naitoh K, Honjo H, Yamamoto T, Urabe M, Ogino Y, Yasumura T, Nambara T. Estrone sulfatase and sulfotransferase activity in human breast cancer and endometrial cancer. J Steroid Biochem. 1989 Dec;33(6):1049-54.

25. Utsumi T, Yoshimura N, Takeuchi S, Maruta M, Maeda K, Harada N. Elevated steroid sulfatase expression in breast cancer. J Steroid Biochem Mol Biol. 2000 Jun;73(34):141-5.

26. Santner SJ, Feil PD, Santen RJ. In situ estrogen production via the estrone sulfatase pathway in breast tumors: relative importance versus the aromatase pathway. J Clin Endocrinol Metab. 1984 Jul;59(1):29-33.

27. Day JM, Tutill HJ, Foster PA, Bailey HV, Heaton WB, Sharland $\mathrm{CM}$ et al. Development of hormone-dependent prostate cancer models for the evaluation of inhibitors of 17beta-hydroxysteroid dehydrogenase type 3. Mol Cell Endocrinol. 2009 Mar;301(1-2):251-8.

28. Nakamura Y, Suzuki T, Fukuda T, Ito A, Endo M, Moriya T et al. Steroid Sulfatase and Estrogen Sulfotransferase in Human Prostate Cancer. Prostate. 2006 Jun;66(9):1005-12.

29. Simard J, Ricketts ML, Gingras S, Soucy P, Feltus FA, Melner $\mathrm{MH}$. Molecular biology of the 3beta-hydroxysteroid dehydrogenase/ delta5-delta4 isomerase gene family. Endocr Rev. 2005 Jun;26(4):525-82.

30. Chang BL, Zheng SL, Hawkins GA, Isaacs SD, Wiley KE, Turner A et al. Joint Effect of HSD3B1 and HSD3B2 Genes Is Associated with Hereditary and Sporadic Prostate Cancer Susceptibility. Cancer Res. 2002 Mar;62(6):1784-9.
31. Stanbrough M, Bubley GJ, Ross K, Golub TR, Rubin MA, Penning TM et al. Increased Expression of Genes Converting Adrenal Androgens to Testosterone in Androgen-Independent Prostate Cancer. Cancer Res. 2006 Mar;66(5):2815-25.

32. Peltoketo H, Luu-The V, Simard J, Adamski J. 17beta-hydroxysteroid dehydrogenase (HSD)/17-ketosteroid reductase (KSR) family; nomenclature and main characteristics of the17HSD/KSR enzymes. J Mol Endocrinol. 1999 Aug;23(1):1-11.

33. Adamski J, Jakob FJ. A guide to 17beta-hydroxysteroid dehydrogenases. Mol Cell Endocrinol. 2001 Jan;171 (1-2): $1-4$.

34. Koh E, Noda T, Kanaya J, Namiki M. Differential expression of 17 beta-hydroxysteroid dehydrogenase isozyme genes in prostate cancer and noncancer tissues. Prostate. 2002 Oct;53(2):154-9.

35. Vihko $P$, Herrala A, Härkönen $P$, Isomaa $V$, Kaija $H$, Kurkela R. et al. Enzymes as modulators in malignant transformation. J Steroid Biochem Mol Biol. 2005 Feb;93 (2-5):277-83.

36. Penning TM, Burczynski ME, Jez JM, Hung CF, Lin HK, Ma $\mathrm{H}$ et al. Human 3alpha-hydroxysteroid dehydrogenase isoforms (AKR1C1- AKR1C4) of the aldo-keto reductase superfamily: functional plasticity and tissue distribution reveals roles in the inactivation and formation of male and female sex hormones. Biochem J. 2000 Oct;351(Pt 1):67-77.

37. Fung KM, Samara EN, Wong C, Metwalli A, Krlin R, Bane $B$ et al. Increased expression of type 23 alpha-hydroxysteroid dehydrogenase/type 5 17beta-hydroxysteroid dehydrogenase (AKR1C3) and its relationship with androgen receptor in prostate carcinoma. Endocrine-Endocr Relat Cancer. 2006 Mar;13(1):169-80.

38. Rizner TL, Lin HK, Peehl DM, Steckelbroeck S, Bauman DR, Penning TM. Human type 3 3alpha-hydroxysteroid dehydrogenase (aldo-keto reductase 1C2) and androgen metabolism in prostate cells. Endocrinology. 2003 Jul; 144(7):2922-32.

39. Lin HK, Jez JM, Schlegel BP, Peehl DM, Pachter JA, Penning TM. Expression and characterization of recombinant type 2 3alpha-hydroxysteroid dehydrogenase (HSD) from human prostate: demonstration of bifunctional 3alpha/17beta-HSD activity and cellular distribution. Mol Endocrinol. 1997 Dec;11(13):1971-84.

40. Wang S, Yang Q, Fung KM, Lin HK. AKR1C2 and AKR1C3 mediated prostaglandin D2 metabolism augments the $\mathrm{PI} 3 \mathrm{~K} / \mathrm{Akt}$ proliferative signaling pathway in human prostate cancer cells. Mol Cell Endocrinol. 2008 Jul;289 (1-2):60-6.

41. Dozmorov MG, Azzarello JT, Wren JD, Fung KM, Yang Q, Davis JS et al. Elevated AKR1C3 expression promotes prostate cancer cell survival and prostate cell-mediated endothelial cell tube formation: implications for prostate cancer progression. BMC Cancer. 2010 Dec;10:672.

42. Isaacs WB, Bova GS, Morton RA, Bussemakers MJ, Brooks JD, Ewing CM. Molecular biology of prostate cancer. Semin Oncol. 1994 Oct;21(5):514-21.

43. Jenkins $E P$, Hsieh $C L$, Milatovich A, Normington $K$, Berman DM, Francke $U$, Russell DW. Characterization and chromosomal mapping of a human steroid 5 alpha-reductase gene and pseudogene and mapping of the mouse homologue. Genomics. 1991 Dec;11(4):1102-12. 
44. Brawley OW, Ford LG, Thompson I, Perlman JA, Kramer BS. 5alpha-reductase inhibition and prostate cancer prevention. Cancer Epidemiol Biomarkers Prev. 1994 Mar;3(2):177-82.

45. Makridakis NM, Ross RK, Pike MC, Crocitto LE, Kolonel $L N$, Pearce $C L$ et al. Association of mis-sense substitution in SRD5A2 gene with prostate cancer in African-American and Hispanic men in Los Angeles, USA. Lancet. 1999 Sep;354(9183):975-8.

46. Kantoff PW, Febbo PG, Giovannucci E, Krithivas K, Dahl DM, Chang $\mathrm{G}$ et al. A polymorphism of the 5alpha-reductase gene and its association with prostate cancer: a casecontrol analysis. Cancer Epidemiol Biomarkers Prev. 1997 Mar;6(3):189-92.

47. Ross RK, Bernstein L, Lobo RA, Shimizu H, Stanczyk FZ, Pike MC, Henderson BE. 5alpha-Reductase activity and risk of prostate cancer among Japanese and US white and black males. Lancet. 1992 Apr;339(8798):887-9.

48. Ellem SJ, Schmitt JF, Pedersen JS, Frydenberg M, Risbridger GP. Local Aromatase Expression in Human Prostate Is Altered in Malignancy. J Clin Endocrinol Metab. 2004 May;89(5):2434-41.

49. Rohrmann S, Roberts WW, Walsh PC, Platz EA. Family history of prostate cancer and obesity in relation to highgrade disease and extraprostatic extension in young men with prostate cancer. Prostate. 2003 May;55(2):140-6.

50. Simpson ER, Mahendroo MS, Nichols JE, Bulun SE. Aromatase gene expression in adipose tissue: relationship to breast cancer. Int J Fertil Menopausal Stud. 1994;39 Suppl 2:75-83.

51. McPherson SJ, Wang $H$, Jones ME, Pedersen J, lismaa $\mathrm{TP}$, Wreford $\mathrm{N}$ et al. Elevated androgens and prolactin in aromatase-deficient mice cause enlargement, but not malignancy, of the prostate gland. Endocrinology. 2001 Jun;142(6):2458-67.

52. Modugno F, Weissfeld JL, Trump DL, Zmuda JM, Shea P, Cauley JA, Ferrell RE. Allelic Variants of Aromatase and the Androgen and Estrogen Receptors: Toward a Multigenic Model of Prostate Cancer Risk. Clin Cancer Res. 2001 Oct;7(10):3092-6.

53. Romero J, Garcia B, Campos F, Touijer KA. Prostate cancer biomarkers: Urol Oncol. 2014 Feb 1.

54. Stone NN, Stock RG, Unger P. Indications for seminal vesicle biopsy and laparoscopic pelvic lymph node dissection in men with localized carcinoma of the prostate. J Urol. 1995 Oct;154(4):1392-6.

55. Kar A, Scholz MC, Fegan JE, Crawford ED, Scardino PT, Kaldate RR, Brawer MK. Cell Cycle Progression (CCP) Score Significantly Modifies Treatment Decisions in Prostate Cancer: Results of an Ongoing Registry Trial ASCO Genitourinary Cancers Symposium, January 30 - February 1, 2014, San Francisco, CA. Poster Presentation.

56. Knezevic D, Goddard AD, Natraj N, Cherbavaz DB, Clark -Langone KM, Snable J et al. Analytical validation of the Oncotype DX Prostate Cancer Assay - A prognostic multi-gene RT-PCR test optimized for needle biopsies. 2013
SUO Annual Meeting - Rockville, MD. Poster Presentation.

57. Marks LS, Fradet Y, Deras IL, Blase A, Mathis J, Aubin SM et al. PCA3 molecular urine assay for prostate cancer in men undergoing repeat biopsy. Urology. 2007 Mar;69(3):532-5.

58. La Rosa FG, Jones C, Crawford ED, Van Neste L. Finding Occult Prostatic Cancer: The Value of Transperineal Mapping Biopsies and Epigenetic Assays. The Journal of OncoPathology, 2013.

59. Robinson K, Creed J, Reguly B, Powell C, Wittock R, Klein $D$ et al. Accurate prediction of repeat prostate biopsy outcomes by a mitochondrial DNA deletion assay. Prostate Cancer Prostatic Dis. 2010 Jun;13(2):126-31.

60. Karantanos T, Corn PG, Thompson TC. Prostate cancer progression after androgen deprivation therapy: mechanisms of castrate resistance and novel therapeutic approaches. Oncogene. 2013 Dec;32(49):5501-11.

61. Vis AN, Schröder FH. Key targets of hormonal treatment of prostate cancer. Part 1: the androgen receptor and steroidogenic pathways. BJU Int. 2009 Aug;104(4):438-48.

62. Mohler JL, Gregory CW, Ford OH, Kim D, Weaver CM, Petrusz $\mathrm{P}$ et al. The androgen axis in recurrent prostate cancer. Clin Cancer Res. 2004 Jan; 10(2):440-8.

63. Locke JA, Guns ES, Lubik AA, Adomat HH, Hendy SC, Wood CA et al. Androgen levels increase by intratumoral de novo steroidogenesis during progression of castration-resistant prostate cancer. Cancer Res. 2008 Aug;68(15):6407-15.

64. Montgomery RB, Mostaghel EA, Vessella R, Hess DL, Kalhorn TF, Higano CS et al. Maintenance of intratumoral androgens in metastatic prostate cancer: a mechanism for castration-resistant tumor growth. Cancer Res. 2008 Jun;68(11):4447-54.

65. Stanbrough M, Bubley GJ, Ross K, Golub TR, Rubin MA, Penning TM et al. Increased expression of genes converting adrenal androgens to testosterone in androgen-independent prostate cancer. Cancer Res. 2006 Mar;66(5):2815-25.

66. Berruti A, Pia A, Terzolo M. Abiraterone and increased survival in metastatic prostate cancer. N Engl J Med. 2011 Aug;365(8):766.

67. Zelefsky MJ, Eastham JA, Sartor OA, Kantoff P. Cancer: Principles \& Practice of Oncology (8th ed.). Philadelphia: Lippincott Williams \& Wilkins. p. 1443.

Correspondence address: Katedra i Zakład Biochemii i Biologii Molekularne 6 Święcickiego Street 60-781 Poznan, Poland phone: +4861 8546513

fax: +48618546510 email: biolmol@ump.edu.pl 